\title{
MJMR THE CORRELATION OF MOTHER'S ROLE WITH TOILET TRAINING ABILITY FOR CHILDREN AS OLD AS 18-36 MONTHS
}

\author{
Monika Sawitri P, Mamik Ratnawati*, Mumpuni Dwiningtyas, Fitri Firanda Nurmalisyah, \\ Pawiono, Heni Maryati \\ STIKES PEMKAB JOMBANG, Jombang, Indonesia \\ Corresponding Author' Email: mamik.perawat@gmail.com
}

\begin{abstract}
Toilet Training for children is an effort to train children in order to be able to control in urinating and defecating. Parents who are less to play an active role and they are less to understand the readiness of children because they have activities with their work or they are lazy to do toilet training will affect many children as old as 18-36 months to get bed wetting. Defecating (BAB) and urinating (BAK) at everywhere, even until school age were caused because of toilet training failure. This research aimed to determine the correlation of mother's role with toilet training ability for children as old as $18-36$ months at Bareng Village, Bareng Sub District, in Jombang District. The design of research used correlation analytic with cross sectional approach. Population in this research was all mothers who had children as old as $18-36$ months at Bareng Village, Bareng Sub District, In Jombang District as many as 325 people. the total of samples was 65 respondents .Sampling technique used cluster random sampling. Research variable consisted of Independent variable was mother's role by using questionnaire. and toilet training ability for children as old as $18-36$ months by using questionnaire, furthermore it was analyzed by using the statistical test of chi square with $\alpha=0,05$. The result of this research showed that the most mother's role were positive as many as 39 respondents $(60 \%)$, the most of toilet training capability for children as old as $19-36$ months were capable as many as 44 respondents $\{$ I 67,7$\}$. The result of Chi square test was obtained $0^{\prime} 000,005$. This research concluded that there were the correlation of mother's role with toilet training ability for children as old as $18-36$ months at Bareng Village, Bareng Sub District, in Jombang District. it is expected that mothers had better practice toilet training to children and avoid using the practical way such as wearing diapers frequently.
\end{abstract}

\section{Keywords: Mother's Role, Toilet Training, Toddler}

\section{INTRODUCTION}

Family in relation to children is identified as a place or institution of care that can give love. Meeting emotional and loving needs can be started as early as possible. Emotional bonding and close affection between parents and children will be useful to determine children's behavior in the future. Families have duties in child development such as giving examples of good behavior, upholding discipline, giving affection, fulfilling educational needs and maintaining children (Nursalam et al. 2010). When children are 18-36 months old parents must begin to exercise their children's ability to urinate and defecate into the toilet. Parents must be patient and understand the child's readiness to start teaching toilet use. Parents also have to have positive support, one example is parents must be ready to deliver children when they want to defecate or urinate into the toilet (Nuhayati, 2011).
Parents do not play an active role and do not understand children's readiness, because some parents are busy with their work or lazy in doing toilet training. This busyness makes parents do not want to bother in taking care of their children. Parents use more practical methods with the use of diapers so that the mother does not have difficulties when the child wants to defecate or small. Busy parents also do not pay attention to the environment in their house that looks dirty, so children are less comfortable with facilities for defecation and defecation as well as parents who do not provide bathroom facilities that are easily accessible to children (Rahayu, 2015).

A survey that was once in Indonesia by the nakita tabloid (2014) states, half a million children aged 6-16 years still love bedwetting, which consists of: $17 \%$ of children aged 5 years, $14 \%$ of children aged 7 years, $9 \%$ of children aged 9 year, and 1-2\% of children aged 15 
years, while about $30 \%$ of children are 4 years old, $10 \%$ of children are 6 years old, $3 \%$ of children are 12 years old and $1 \%$ of children are 18 years old still wet their bed. There are also around $20 \%$ of children under five not doing toilet training and $75 \%$ of parents do not view such conditions as a problem.

Based on preliminary studies conducted by researchers on March 9, 2017 using a questionnaire in Bareng Village, Bareng District, Jombang Regency of 10 respondents who had children aged 18-36 months, it was found that 6 children were still wet because their role in toilet training was lacking, 2 children have enough toilet training and 2 children can do toilet training or are already good.

Toilet training in children is an attempt to train children to be able to control urination and defecation. This toilet training can take place at the stage of a child's life at the age of 18 months to 36 months. The problem arising from the above incident is that many children aged 1836 months who wet their bed, defecation and bladder were banned, even to school age due to the failure of toilet training. This will adversely affect the future development of children. The impact caused by parents who do not implement toilet training among children is that children become stubborn and unruly. In addition, children are not independent and still carry the habit of wet the bed. Toilet training that is not taught early will make it more difficult for parents to teach children when children get older (Firdaus, 2014).

Children generally have not learned to use the toilet until they are 3 years old. Boys usually learn to use the toilet for 6 months and longer than girls. Most health experts suggest that toilet training should be done when children begin to show interest in learning toilet training (Karen, 2010). Children who use diapers, usually will experience delays in toilet training. The delay is due to the child feeling that there is no need to go to the toilet because when using a diaper they still feel comfortable despite having done BAK. Generally, children who use diapers are starting to be interested in toilet training at the age of 4 years, even in some cases children begin learning toilet training at the age of 7 years. Many things that cause toilet training failures include the use of diapers, starting toilet training at the wrong time, forcing children and punishing children. The use of diapers should be stopped when the child is 2 years old because with the use of diapers the child will not be trained to control when it is time to defecate and bladder.
In children aged 18-36 months, if toilet training is carried out properly, children should not wet their bed during the day. Parents should not punish and scold children in applying toilet training because almost no child does remember to wet his bed (Hendi, 2010).

The benefit of applying children's training toilets is to train children to live in discipline, be responsible, foster self-confidence and shape children to master themselves. All the benefits of applying toilet training are conducted simultaneously to train motor skills and sharpen independence (Rahadiasih, 2010). Parents should play a more active role in seeking information through the media. The media include books and the internet that contain the importance of toilet training education in children aged 18-36 months. Parents can train toilet training as early as possible for their children, so that they will not increase their bedwetting and defecation and defecation.

Based on the background above, the researcher was interested in conducting research on the relationship of the role of mothers with toilet training abilities in children aged 18-36 months in Bareng Village, Bareng District, Jombang Regency.

\section{METHODS}

The design of the research in this study is analytic correlation with the cross sectional approach. The population in this study were all mothers who had children aged 18-36 months in Bareng Village, Bareng District, Jombang Regency, amounting to 325 people. The sample used was 65 respondents with cluster random sampling.

\section{Measure}

The variable of this study consisted of independent variables, namely the role of the mother using a questionnaire and the ability of toilet training in children aged 18-36 months using a questionnaire then analyzed using the chi square test.

\section{Statistical analysis}

To prove the hypothesis of this study using the chi square test with alpha 0.001

\section{RESULT}

The results of the research obtained in the study of the Relationship between the Role of Mothers and Toilet Training Ability in Children 18-36 Months in Bareng 
Village, Bareng District, Jombang Regency on April 13-21 2018 are as follows:

Table 1 shows that the majority of respondents aged 20 35 years were 40 respondents $(61.5 \%)$. Most of the respondents had basic education (elementary, junior high), which was 41 respondents (63.1\%). Most of the respondents did not work namely 44 respondents $(67.7 \%)$. Almost all respondents had received information about toilet training, namely 54 respondents $(83.1 \%)$. Most of them get information from health workers, namely 31 respondents $(57.4 \%)$. Most of the children aged 18-24 months were 35 respondents $(53.8 \%)$. And most of the sex of boys is 33 respondents $(50.8 \%)$.

Table 2 shows that the majority of maternal roles are positive, namely 39 respondents $(60 \%)$

Table 3 shows that the majority of toilet training capabilities in children aged 18-36 months are capable of a number of 44 respondents $(67.7 \%)$.

Table 4 that of the 39 respondents the role of positive mothers was almost entirely the ability of toilet training in the category of capable of 34 people (87.2\%)

\section{DISCUSSION}

From the results of the chi square statistical test obtained significant numbers or probability values $(0,000)$ far lower significant standard 0.05 or $(r<a)$, due to $\mathrm{r}<\mathrm{a}$, which means there is a relationship of the role of mothers with toilet training abilities in children aged 18- 36 months in Bareng Village, Bareng District, Jombang Regency. From the results of the Contingency Coefficient statistical test obtained significant numbers with a value of 0.455 means in the medium category. Role is a behavior associated with someone who holds a certain position, a position identifying a person's status or place in a social system (Friedman, 2010). According to (Rahayu, 2015) affection and mother's role influence the implementation of early toilet training, where the attention of the mother will monitor the development of children aged 18-36 months, it will have a faster effect in training children aged 18-36 months to do toilet training early. With the role of mother, the child will be more courageous or motivated to try because they get attention and guidance. According to the researchers, this study has a conformity with the facts above where mothers who have a positive role in implementing toilet training almost all have children who are able to do toilet training. Through training toilets, children will be taught by parents to be responsible for doing $\mathrm{BAB}$ or BAK activities in their place and avoid defecating or urinating in places. But the results of the study also found a slight gap where there were still mothers who had a negative role but their children were able to do toilet training as many as 10 respondents (38.5\%). This could be because parents do not wear diapers on their children so that children are not used to defecating and smacking their pants. In addition, physical, mental and cognitive readiness in children aged 18-36 months so naturally children are able to not wet their bed for 2 hours, imitate parents while in the bathroom and curiosity about the toilet habits of their older siblings or parents. That way even though the role of parents is not optimal or has a negative role, the child is able to do toilet training.

\section{CONCLUSION}

1. The role of mothers in Bareng Village, Bareng SubDistrict, Jombang Regency is mostly 39 respondents $(60 \%)$.

2. The ability of toilet training in children aged 18-36 months in Bareng Village, Bareng District, Jombang Regency is mostly capable of 44 respondents $(67.7 \%)$.

3 . There is a relationship between mother's role and toilet training ability in children aged 18-36 months in Bareng Village, Bareng District, Jombang Regency in the medium category $(0.455)$.

\section{REFERENCE}

Firdaus, 2014. Toilet training pada anak. Retrieved From: http://journal.unusa.ac.id/index.php. Diakses 29/01/2017

Friedman, 2008. Faktor model peran. Retrieved From: http://eprints.uns.ac.id/877.pdf. Diakses 18/02/2017

Hendi, 2010. Toilet training pada anak. Retrieved From: http://journal.unusa.ac.id/index.php. Diakses 29/01/2017

Karen, 2010. Manfaat toilet training pada anak. Retrieved From: http://journal.unusa.ac.id/index. php. Diakses 29/01/2017

Nursalam, N., Hanafi, N.C., Ulfiana, E. (2010) The Elderly's Satisfaction With The Service Quality Of A Community Geriatric Health Programme In Indonesia: A Cross-Sectional Study. Journal Ners. 
12(2) pp: $225-232$

Octavia, S., Rahadi Asih, S., Jaya, E.S., (2010). Manfaat dari penerapan toilet training anak. Retrieved From: https://www.researchgate. net/publication/337366212_Does_negative-selfschema_link_the_relationship_between_childhoo d_trauma_and psychotic_symptoms_in_a_comm unity_sample_of_Indonesians

Rahayu, 2015. Hubungan Peran Orang Tua Dengan Kemampuan Toilet Training Pada Anak Usia Toddler Di Paud Permata Bunda Rw 01 Desa Jati
Selatan 1 Sidoarjo, Journal Ilmiah Kesehatan. 8(1) pp: 68-75

Widowati, W., Nurhayati, N., Nurhayati, S. L., Widowati, W.N.S., 2011. Dynamic Analysis Of Ethanol, Glucose, And Saccharomyces For Batch Fermentation. Retrieved From: https://www. semanticscholar.org/paper/DYNAMICA N A L Y S I S - O F - E T H A N O L \% 2 C GLUCOSE\%2C-AND-FOR-BATCH-WidowatiNurhayati/507601fbe5ca4c433a97ebf23f2f17a50f $469 \mathrm{bff}$ 